doi: $10.2306 /$ scienceasia1513-1874.2013.39.346

\title{
Activity of organic acid salts in combination with lauric arginate against Listeria monocytogenes and Salmonella Rissen
}

\author{
Suchart Suksathit $^{\mathrm{a}}$, Pussadee Tangwatcharin ${ }^{\mathrm{b}, *}$ \\ a Faculty of Technology and Community Development, Thaksin University Phatthalung Campus, \\ Phatthalung 93110 Thailand \\ b Faculty of Agricultural Technology, King Mongkut's Institute of Technology Ladkrabang, \\ Bangkok 10520 Thailand
}

*Corresponding author, e-mail: putang3009@hotmail.com

Received 15 Mar 2013

Accepted 16 May 2013

\begin{abstract}
The objective of this study was to investigate the in vitro activities of sodium diacetate (SD), sodium citrate (SC), or sodium lactate (SL) in combination with lauric arginate (LAE) against Listeria monocytogenes and Salmonella Rissen. Bacteria isolated from a pig carcass were used to determine the minimum inhibitory and bactericidal concentrations (MIC and MBC), fractional bactericidal concentration index (FBCI), time-kill method, as well as to perform scanning and transmission electron microscopy characterizations. For L. monocytogenes, the MBC of SD, SC, LAE and SL were 62.5, $62.5,0.032 \mathrm{mg} / \mathrm{ml}$, and $8.4 \%$ (v/v), respectively. As for $S$. Rissen, the MBC of SD and LAE were $62.5 \mathrm{and} 0.032 \mathrm{mg} / \mathrm{ml}$, respectively. The effects of SD, SC, and SL in combination with LAE were synergistic against both bacteria, exhibiting FBCIs of $0.19,0.50$, and 0.50 , respectively, for L. monocytogenes and $0.19, \leqslant 0.50$ and $\leqslant 0.50$, respectively, for $S$. Rissen. In time-kill studies, all salts of organic acids plus LAE combinations added at their MBC produced a bactericidal effect that was dependent on the type of bacteria and antimicrobial. This resulted in a loss and change of the cytoplasm and membrane in cells of both bacteria. Furthermore, SC and SL alone were not active in killing S. Rissen. The present investigation revealed that salts of organic acid in combination with LAE are potentially antilisterial and anti-salmonella agents, which can be applied to meat products.
\end{abstract}

KEYWORDS: sodium diacetate, sodium citrate, sodium lactate, lauroyl arginate ethyl, pathogenic foodborne bacteria

\section{INTRODUCTION}

Listeria monocytogenes and Salmonella spp. are the pathogenic foodborne bacteria ${ }^{1,2}$. Salmonellae are most often associated with any raw food of animal origin which may be subject to faecal contamination, especially raw meat and poultry ${ }^{2}$. Salmonella testing in the slaughter environment is important as intestinal pathogens are carried into the abattoir in the bowels and on the skin of the animals ${ }^{3}$. In pork carcasses, a prevalence of Listeria spp. and Salmonella spp. can be as high as $23 \%$ and $100 \%$, respectively, from floor slaughtering process and $12 \%$ and $56 \%$, respectively, from hanging slaughtering process in abattoirs of Southern Thailand. Furthermore, L. monocytogenes was the third most specie of Listeria isolate in carcasses from both slaughtering processes (28\% and $25 \%$, respectively). Salmonella Rissen was the most frequently found serotype of Salmonella isolate in carcasses from both slaughtering processes $(32 \%$ and $37 \%$, respectively $)^{4,5}$.
Safe preservation in the meat industry is complicated, as nowadays products require more safety and greater assurance of protection from pathogens. Many attempts have been made to control the growth of pathogens on the surface of meat and meat products by using chemical antimicrobials. Salts of organic acid are commonly used to control the growth of undesirable microorganisms. Several treatments using organic acids or their salts have been demonstrated to be effective at reducing populations of spoilage and pathogenic bacteria on, or in, meat or meat products. However, the study of the antimicrobial effects of organic acid salts on spoilage bacteria growth by incorporating them during the preparation of meat products is limited. Conversely, extensive research has examined the effect of lactate and diacetate on the viability of pathogens such as Salmonella spp. during refrigerated storage of vacuum-packaged meat products dipped or sprayed with chemicals ${ }^{6}$. Citric and lactic acid salts have been considered as preservatives in a number of meat systems ${ }^{7}$. 2\% (w/w) sodium 
lactate (SL) or $2 \%(\mathrm{w} / \mathrm{w})$ sodium citrate (SC) or $1.5 \%$ $(\mathrm{w} / \mathrm{w}) \mathrm{SC}+1.5 \%(\mathrm{w} / \mathrm{w})$ SL into fresh pork sausage has been found to be effective in reducing contamination by Salmonella Kentucky ${ }^{8}$.

Lauroyl arginate ethyl (LAE) is a new surfactant derived from lauric acid and arginine whose antimicrobial properties have been shortly described in literature. In addition to these advantages, the antimicrobial properties of LAE remain stable from $\mathrm{pH} 3$ to $\mathrm{pH} 7$, suggesting that this substance may be useful as antimicrobial agent for a wide range of food ${ }^{9}$. Toxicological studies have determined that LAE was rapidly metabolized by humans to the naturally occurring dietary components lauric acid and arginine ${ }^{10}$ and thus it is considered as a safe product. Besides, LAE has been Generally Recognized as Safe by the FDA in 2005. Hence LAE represents a potential non odorous alternative to essential oils for the development of new food preservation alternatives including antimicrobial active packaging ${ }^{9}$.

The individual effectiveness of salts of organic acid or LAE against foodborne pathogenic bacteria has been examined ${ }^{6-9}$. The aim of this study was to compare the antibacterial activity of sodium diacetate (SD), SC, SL, and LAE on the growth of L. monocytogenes and $S$. Rissen isolated from pig carcasses.

\section{MATERIALS AND METHODS}

\section{Test strains}

L. monocytogenes TSULM1 and $S$. Rissen TSUSR1 used in the present study were previously isolated from pig carcasses from southern Thailand abattoirs using the standard procedure ${ }^{11,12}$ and its identity confirmed by the Department of Medical Sciences, Ministry of Public Health of Thailand. These organisms were maintained on Mueller Hinton agar (MHA, Merck, Germany). Overnight cultures were prepared by inoculating approximately $2 \mathrm{ml}$ Mueller Hinton broth (MHB, Merck, Germany) with 2-3 colonies taken from MHA. Broths were incubated overnight at $35^{\circ} \mathrm{C}$. Inocula were prepared by diluting overnight culture in saline to $10^{8} \mathrm{CFU} / \mathrm{ml}$ (McFarland standard of 0.5). These suspensions were further diluted with saline as required. An initial concentration of approximately $5 \times 10^{5} \mathrm{CFU} / \mathrm{ml}$ was used for the susceptibility, synergy and kill-time tests.

\section{Antimicrobial agents}

SD and SC were supplied by Chemipan Corporation Co. Ltd. (Bangkok). SL was provided by Purac Inc. (Bangkok). LAE was obtained from A\&B Ingredients (Fairfield, NJ, USA). All antibacterials were food grade. For the agar disk diffusion and broth dilution assays, the concentrations of SD, SC, and LAE were assessed as $\mathrm{mg} / \mathrm{ml}$, but for SL the concentrations were measured as \% (v/v).

\section{Susceptibility test methods}

Susceptibility tests were performed by the disk diffusion method of Bauer et al ${ }^{13}$ with MHA. All the antimicrobials were dissolved in distilled water. Subsequent two-fold serial dilutions were performed in culture medium so that the final concentrations of the test samples on disks ranged from $0-62.5 \mathrm{mg} / \mathrm{ml}$ for SD and SC, $0-8.4 \%(\mathrm{v} / \mathrm{v})$ for SL and $0-0.128 \mathrm{mg} / \mathrm{ml}$ for LAE. Zones of inhibition were measured after $18 \mathrm{~h}$ of incubation at $35^{\circ} \mathrm{C}$.

The minimal inhibitory concentration (MIC) was determined by a broth microdilution method ${ }^{14}$ for each bacterium. Serial two-fold dilutions of the test substances were mixed with MHB in microtitre plates. The final concentrations of the inhibitors in the broth were the same as those used for the disk diffusion method. A $20 \mu \mathrm{l}$ aliquot of the inoculum suspension was added to each well. Then, the inoculated plates were incubated at $35^{\circ} \mathrm{C}$ for $18 \mathrm{~h}$. The MIC was recorded as the lowest concentration that limited the turbidity of the broth to $<0.05$ at absorbance of $600 \mathrm{~nm}$ by UVM 340 Microplate Reader (Biochrom Ltd., Cambridge, UK). Solvent controls were also included, though no significant effect on bacterial growth was observed at the highest concentration employed.

The minimal bactericidal concentration (MBC) was determined by comparing the number of remaining viable bacteria with the initial number of bacteria. All wells from the MIC experiments that showed no visible turbidity were serially diluted and spread onto MHA plates for viable cell counting. The plates were incubated for 24-48 h. The MBC was then recorded as the lowest concentration that killed at least $99.99 \%$ of the initial number of bacteria. All MIC and MBC experiments were repeated three times.

\section{Synergistic effects}

To determine whether lauric acid or monolaurin acted synergistically with lactic acid, the fractional inhibitory concentration index (FICI) and fractional bactericidal concentration index (FBCI) in MHB using chequerboard titration was estimated. The experiments were repeated three times and the mean MIC, MBC, FICI, and FBCI were obtained. Synergy was indicated by an FICI and FBCI $<0.5$; partial synergy/additive effect was apparent when the FICI and FBCI ranged from $>0.5-1.0$; an FICI and FBCI 
of $>1$ to $<2$ suggested that there was no interaction, and antagonism was exhibited when the FICI and FBCI was $>2^{15-18}$.

\section{Determination of kill-time}

The effect of SD, SC, LAE, and SL alone (62.5, $62.5,0.032 \mathrm{mg} / \mathrm{ml}$, and $8.4 \%(\mathrm{v} / \mathrm{v})$, respectively) and in combinations of SD $(7.8 \mathrm{mg} / \mathrm{ml})$ and LAE $(0.002 \mathrm{mg} / \mathrm{ml}), \quad$ SC $(15.6 \mathrm{mg} / \mathrm{ml})$ and LAE $(0.008 \mathrm{mg} / \mathrm{ml}), \mathrm{SL}(2.1 \% \mathrm{v} / \mathrm{v})$ and LAE $(0.008 \mathrm{mg} / \mathrm{ml})$ on the cell viability of $L$. monocytogenes and $S$. Rissen over $12 \mathrm{~h}$ was evaluated by the viable cell count procedure. To do so, $8 \mathrm{ml}$ of MHB was inoculated with $1 \mathrm{ml}$ of the bacterial inoculum of $L$. monocytogenes TSULM1 and $S$. Rissen TSUSR 1 and $1 \mathrm{ml}$ of antimicrobial solution (final concentration as shown above) was combined and gently shaken for $30 \mathrm{~s}$. The resulting suspension was incubated at $35^{\circ} \mathrm{C}^{18}$. At different time intervals $(0,5,10,15,30,60,120$, 180,360 , and $720 \mathrm{~min}$ ), the cells that were capable of growth on solid selective media were enumerated using spread plate count on MHA in order to determine the total culturable population. When the concentration of culturable cells was $<300 \mathrm{CFU} / \mathrm{ml}$, a portion $(0.1 \mathrm{ml})$ of each resuspension was plated onto MHA. When the culturable cell counts were lower than the detection limit, culturability was assessed by plating $1 \mathrm{ml}$ on MHA. Two $0.3 \mathrm{ml}$ aliquots or a $0.4 \mathrm{ml}$ aliquot of each resuspension were added onto MHA ${ }^{19}$. The cell numbers (CFU) were determined following incubation at $35^{\circ} \mathrm{C}$ for $48 \mathrm{~h}$.

\section{Scanning electron microscopy (SEM) and transmission electron microscopy (TEM)}

SEM and TEM were performed using a modification of methods described ${ }^{19-21}$. L. monocytogenes TSULM1 and $S$. Rissen TSUSR1 samples for SEM and TEM were centrifuged at $16000 \mathrm{~g}$ for $5 \mathrm{~min}$ and the supernatant was discarded. The pellets were washed 3 times with Sorensen's phosphate buffer (SPB), and subsequently fixed in $2.5 \%$ glutaraldehyde in SPB for $1-2 \mathrm{~h}$ at $4{ }^{\circ} \mathrm{C}$, followed by $1 \%$ osmium in SPB for $1-2 \mathrm{~h}$. The sample was washed 3 times with SPB between fixatives. The pellets were dehydrated by passage through a graded ethanol series $(3 \times 5 \mathrm{~min}$ each at 50,70, 80, 90, and 95 and $2 \times 10 \mathrm{~min}$ at $100 \% \mathrm{v} / \mathrm{v}$ ) and then stored overnight. For SEM, the sample was dehydrated to the critical point drying using a Polaron CPD 7501 (VG Microtech, UK). The dried specimens were mounted onto a stub with double-sided carbon tape. The specimens were coated with a thin layer of gold by a Sputter Coater (SPI suppliers, USA) prior to examination with a Quanta
400 scanning electron microscope (FEI Ltd., Czech Republic). For TEM, ethanol was replaced with propylene oxide, which was gradually replaced with Spurr's resin (Polysciences, Warrington, PA). Following polymerization, specimen blocks were thin sectioned $(70-90 \mathrm{~nm})$. Sections were stained with 5\% uranyl acetate and $10 \%$ lead citrate for examination with a JEM-2010 transmission electron microscope (JEOL Ltd., USA) operated at $160 \mathrm{kV}$.

\section{Statistical analysis}

Data are presented as means and standard deviations. All statistical computations were performed to determine significant differences $(p<0.05)$ by ANOVA followed by Duncan's new multiple range test.

\section{RESULTS AND DISCUSSION}

\section{Susceptibility test}

The results of the antimicrobial activity of salts of organic acid and LAE tested by the disk diffusion method against L. monocytogenes TSULM1 and $S$. Rissen TSUSR1 are given in Fig. 1 and Fig. 2. $\mathrm{SD}$, and LAE exhibited a favourable activity against both bacteria tested. They were inhibited at $>$ $3.91 \mathrm{mg} / \mathrm{disc}$ of SD for both bacteria and $>0.004$ and $>0.008 \mathrm{mg} / \mathrm{disc}$ of LAE for L. monocytogenes TSULM1 and $S$. Rissen TSUSR1, respectively. SC and SL inhibited L. monocytogenes TSULM1 but did not inhibit $S$. Rissen TSUSR1. They were inhibited L. monocytogenes TSULM1 at $>7.8 \mathrm{mg} / \mathrm{disc}$ of $\mathrm{SC}$ and $>2.1 \%(\mathrm{v} / \mathrm{v}) /$ disc of SL. The findings of this study are in agreement with those of other researchers for the efficacy of salts of organic acid in inhibiting the growth of food-related pathogens ${ }^{6,22,23}$. It has long been known that salts of organic acid have an inhibitory effect on L. monocytogenes ${ }^{24-28}$ and Salmonella ${ }^{25,29}$. Salts of organic acid have also been suggested to have antimicrobial effects by causing hyper-acidification via proton donation at the plasma membrane interface of the microorganism and intracellular cytosolic acidification, an excess of which can disrupt the $\mathrm{H}^{+}$-ATPase enzyme required for ATP synthesis ${ }^{24,28}$. Furthermore, the growthdelaying effect of lactate on $L$. monocytogenes in food products or microbiological growth media has also been reported by ${ }^{30-33}$. Gram-positive bacteria are more sensitive towards lactate than Gram-negative bacteria ${ }^{34}$. The antimicrobial activity of sodium citrate has been attributed to its strong chelating activity ${ }^{35}$. LAE interacts with the lipids from the bacterial membranes, producing disturbance in membrane potential and structural changes in $S$. Typhimurium and 

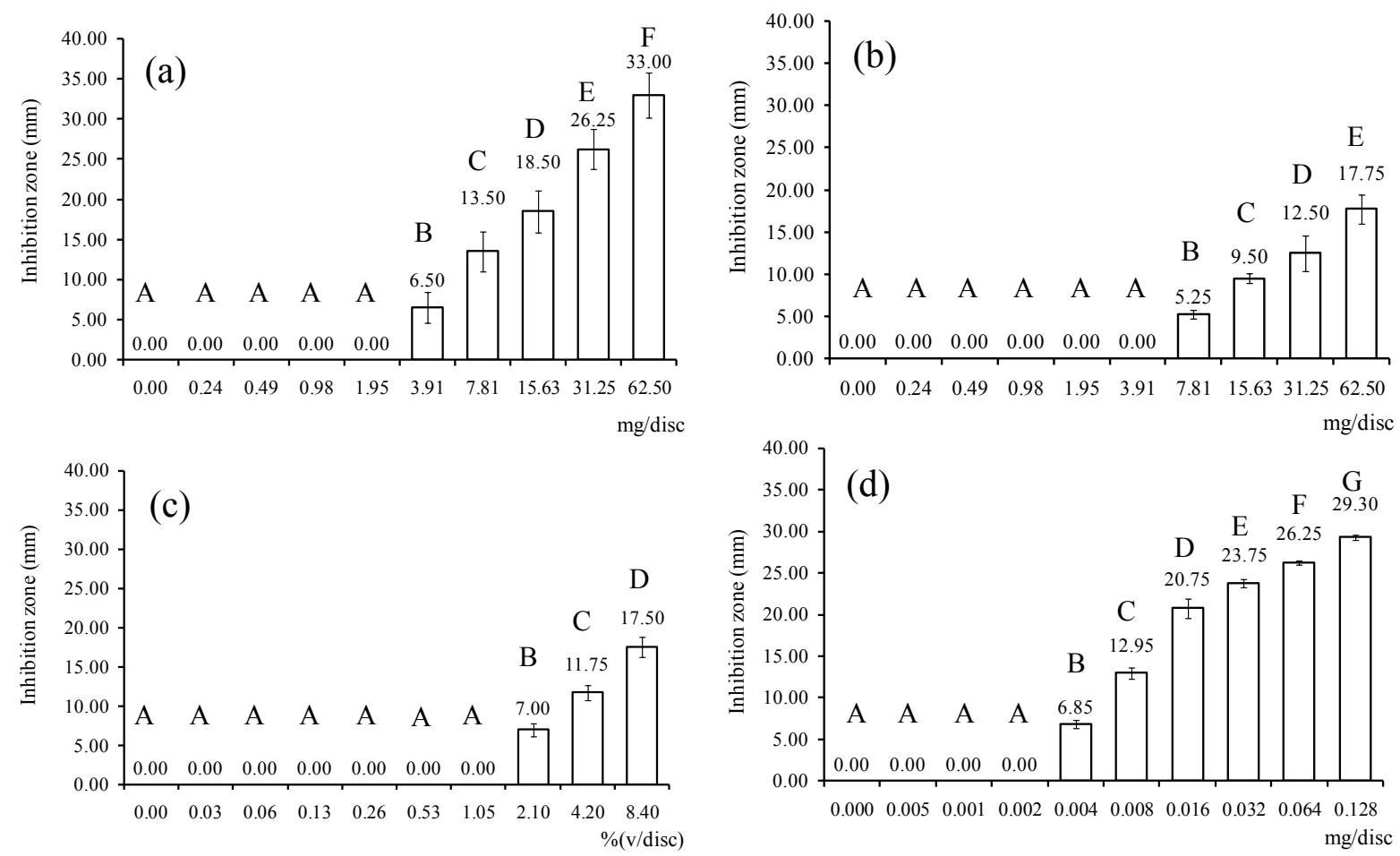

Fig. 1 Antimicrobial activity (zone of inhibition) of (a) SD, (b) SC, (c) SL, and (d) LAE against L. monocytogenes TSULM1. Different letters $(A-G)$ indicate that values are significantly different $(p<0.05)$.

Staphylococcus aureus ${ }^{9}$.

In addition, the MICs of antibacterial against L. monocytogenes TSULM1 were determined to be $31.3 \mathrm{mg} / \mathrm{ml}$ for SD, $15.6 \mathrm{mg} / \mathrm{ml}$ for SC, $2.1 \%$ (v/v) for $\mathrm{SL}$ and $0.008 \mathrm{mg} / \mathrm{ml}$ for LAE. The MICs of SD and LAE against $S$. Rissen TSUSR1 were determined to be 31.3 and $0.016 \mathrm{mg} / \mathrm{ml}$, respectively. However, the MBCs of antibacterial against both bacteria were twofold for SD and four-fold for SC and SL, respectively, higher than the corresponding MIC. The MBCs of LAE against $L$. monocytogenes TSULM 1 and $S$. Rissen TSUSR1 were both $0.032 \mathrm{mg} / \mathrm{ml}$, or four- and two-fold, respectively, higher than the corresponding MIC (Table 1). Earlier studies found MIC of SD, SC, SL, and LAE against L. monocytogenes in the range of $4.00-5.00 \mathrm{mg} / \mathrm{ml}^{36,37}, 70 \mathrm{mg} / \mathrm{ml}^{38}, 2.5-4.8 \%$ $(\mathrm{v} / \mathrm{v})^{38-40}$, and $0.0125-0.025 \mathrm{mg} / \mathrm{ml}^{9,41}$, respectively.

\section{Synergistic effects}

The FICI for the combined application of organic acid salts with LAE on L. monocytogenes TSULM1 and $S$. Rissen TSUSR 1 is shown in Table 2. FICI and FBCI indicate that application of organic acid salts in combination with LAE resulted in enhanced inhibition of both pathogens. The enhancing effect of the combination was also evidenced by bactericidal
Table 1 The MIC and MBC values of salts of organic acid and LAE against L. monocytogenes TSULM1 and S. Rissen TSUSR1.

\begin{tabular}{lcccccc}
\hline Antimicrobials & \multicolumn{2}{c}{$\begin{array}{c}\text { L. monocytogenes } \\
\text { TSULM1 }\end{array}$} & & \multicolumn{2}{c}{$\begin{array}{c}\text { S. Rissen } \\
\text { TSUSR1 }\end{array}$} \\
\cline { 2 - 3 } \cline { 6 - 7 } & MIC & MBC & & MIC & MBC \\
\hline SD $(\mathrm{mg} / \mathrm{ml})$ & 31.3 & 62.5 & & 31.3 & 62.5 \\
SC $(\mathrm{mg} / \mathrm{ml})$ & 15.6 & 62.5 & & NI & NI \\
SL $(\mathrm{mg} / \mathrm{ml})$ & 2.1 & 8.4 & & NI & NI \\
LAE $(\% \mathrm{v} / \mathrm{v})$ & 0.008 & 0.032 & & 0.016 & 0.032 \\
\hline
\end{tabular}

SD, sodium diacetate; SC, sodium citrate; SL, sodium lactate; LAE, lauric arginate.

* NI, no inhibition.

responses produced at sub-MBC levels for each bacterium. FICIs of the combined action of SD + LAE, $\mathrm{SC}+\mathrm{LAE}$, and $\mathrm{SL}+\mathrm{LAE}$ were $0.25(3.91 \mathrm{mg} / \mathrm{ml}+$ $0.001 \mathrm{mg} / \mathrm{ml}), 0.50(3.91 \mathrm{mg} / \mathrm{ml}+0.002 \mathrm{mg} / \mathrm{ml})$, and $0.38(0.26 \%(\mathrm{v} / \mathrm{v})+0.002 \mathrm{mg} / \mathrm{ml})$, respectively, for L. monocytogenes TSULM1 and $0.38(1.95 \mathrm{mg} / \mathrm{ml}+$ $0.002 \mathrm{mg} / \mathrm{ml}),<0.38(3.91 \mathrm{mg} / \mathrm{ml}+0.002 \mathrm{mg} / \mathrm{ml})$ and $<0.50(1.05 \%(\mathrm{v} / \mathrm{v})+0.002 \mathrm{mg} / \mathrm{ml})$, respectively, for $S$. Rissen TSUSR1 suggesting synergy of the assayed antimicrobials. Similarly, FBCIs of the combined 
Table 2 FICI and FBCI of the combined action of lipid with lactic acid to L. monocytogenes TSULM1 and $S$. Rissen TSUSR1.

\begin{tabular}{|c|c|c|c|c|c|}
\hline \multirow[t]{2}{*}{ Strain } & \multirow[t]{2}{*}{ Combination $^{*}$} & \multicolumn{2}{|c|}{$\mathrm{FICI}^{\dagger}$} & \multicolumn{2}{|c|}{$\mathrm{FBCI}^{\dagger}$} \\
\hline & & Concentration ${ }^{+}$ & Value & Concentration $^{\ddagger}$ & Value \\
\hline \multirow[t]{3}{*}{ L. monocytogenes TSULM1 } & $\mathrm{SD}+\mathrm{LAE}$ & $3.91+0.001$ & 0.25 & $7.8+0.002$ & 0.19 \\
\hline & $\mathrm{SC}+\mathrm{LAE}$ & $3.91+0.002$ & 0.50 & $15.6+0.008$ & 0.50 \\
\hline & $\mathrm{SL}+\mathrm{LAE}$ & $0.26+0.002$ & 0.38 & $2.1+0.008$ & 0.50 \\
\hline \multirow[t]{3}{*}{$S$. Rissen TSUSR1 } & $\mathrm{SD}+\mathrm{LAE}$ & $1.95+0.002$ & 0.19 & $7.8+0.002$ & 0.19 \\
\hline & $\mathrm{SC}+\mathrm{LAE}$ & $3.91+0.002$ & $<0.16$ & $15.6+0.008$ & $<0.50$ \\
\hline & $\mathrm{SL}+\mathrm{LAE}$ & $1.05+0.002$ & $<0.25$ & $2.1+0.008$ & $<0.50$ \\
\hline
\end{tabular}

* SD, sodium diacetate; SC, sodium citrate; SL, sodium lactate; LAE, lauric arginate.

FICI, fractional inhibitory concentration index; FBCI, fractional bactericidal concentration index.

$\doteqdot$ The units of antimicrobial concentration are $\mathrm{mg} / \mathrm{ml}$ for $\mathrm{SD}, \mathrm{SC}$, and $\mathrm{LAE}$ and $\%(\mathrm{v} / \mathrm{v})$ for $\mathrm{SL}$.
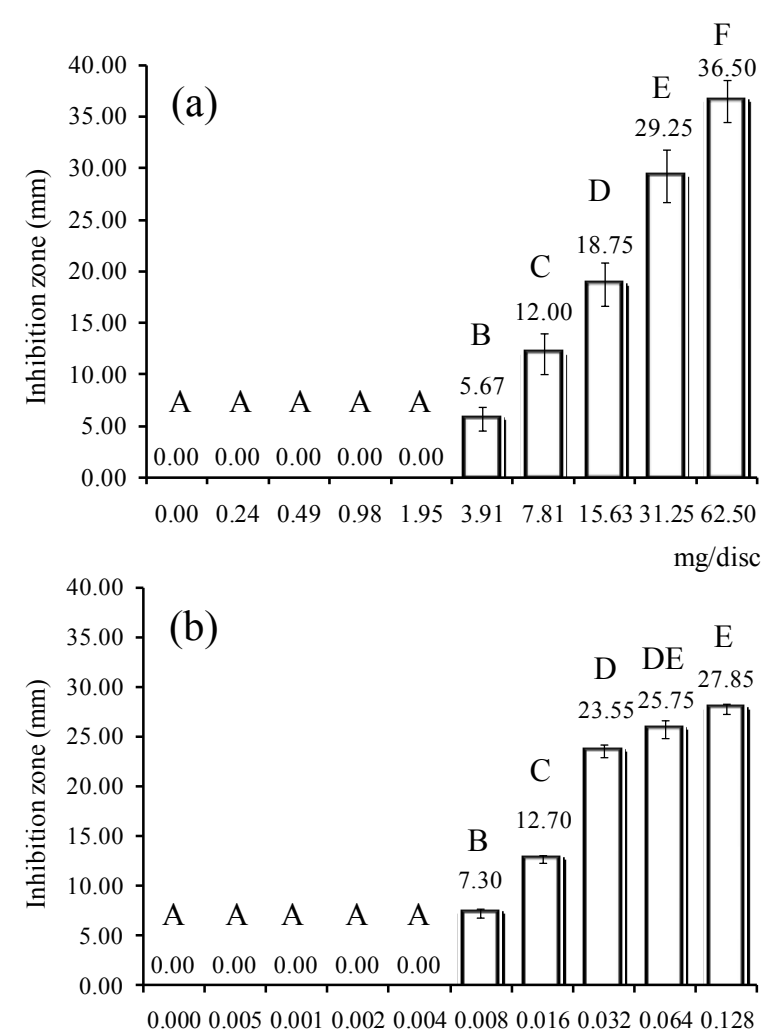

$\mathrm{mg} / \mathrm{disc}$

Fig. 2 Antimicrobial activity (zone of inhibition) of (a) SD and (b) LAE against $S$. Rissen TSUSR1. Different letters (A-F) indicate that values are significantly different $(p<$ $0.05)$.

action of SD + LAE, SC + LAE, and SL + LAE were $0.19(7.8 \mathrm{mg} / \mathrm{ml}+0.002 \mathrm{mg} / \mathrm{ml}), 0.50(15.6 \mathrm{mg} / \mathrm{ml}+$ $0.008 \mathrm{mg} / \mathrm{ml})$, and $0.50(2.1 \%(\mathrm{v} / \mathrm{v})+0.008 \mathrm{mg} / \mathrm{ml})$, respectively, for L. monocytogenes TSULM1 and 0.19 $(7.8 \mathrm{mg} / \mathrm{ml}+0.002 \mathrm{mg} / \mathrm{ml}),<0.50(15.6 \mathrm{mg} / \mathrm{ml}+$
$0.008 \mathrm{mg} / \mathrm{ml})$, and $<0.50(2.1 \%(\mathrm{v} / \mathrm{v})+0.008 \mathrm{mg} / \mathrm{ml})$, respectively, for $S$. Rissen TSUSR1 again suggesting synergy. The test strain was able to grow at subbactericidal concentrations ( $\frac{1}{2} \mathrm{MIC}$ and $\left.\frac{1}{4} \mathrm{MIC}\right)$ of all antimicrobials when applied alone (data not shown). The subsequent calculation and analysis of FICIs and FBCIs (presented in Table 2) indicate that application of organic acid salt with LAE resulted in synergistic inhibition of the pathogen, potentially resulting from salts of organic acid, SD, SC, and SL, a weak organic acid salt was effective in inhibiting most tested bacteria. In addition, the synergistic effect is mainly due to the dissociation effect of LAE caused by the presence of organic acids. The pKa of lactic acid is 3.5, whereas that of citric acid is 3.15 , and that of diacetic acid 3.58 or 3.77 depending on the source ${ }^{42-44}$. Undissociated acid molecules are able to penetrate rapidly through the bacterial cell membrane, dissociating and acidifying the cell interior. When the internal $\mathrm{pH}$ of cells decreases below a certain threshold value, cellular functions are inhibited ${ }^{45}$. Sodium lactate dissociates into uncharged acid molecules, anions and cations ${ }^{46}$. Furthermore, the inhibitory effect of sodium lactate and sodium citrate were probably due to their chelating properties ${ }^{42}$. Lactate and citrate are able to chelate a large portion of the metallic nutrient ions, depleting the cell of its essential nutrients ${ }^{47}$. In addition, the LAE interacts with the lipids from the bacterial membranes, producing disturbance in membrane potential and structural changes in Gram positive and Gram negative bacteria and sensitize the cell to undissociated salts of organic acid ${ }^{48}$.

\section{Time-kill}

To determine the rates at which bacteria were killed, L. monocytogenes TSULM1 and S. Rissen TSUSR1 were exposed to SD, SC, SL, and LAE alone and in 


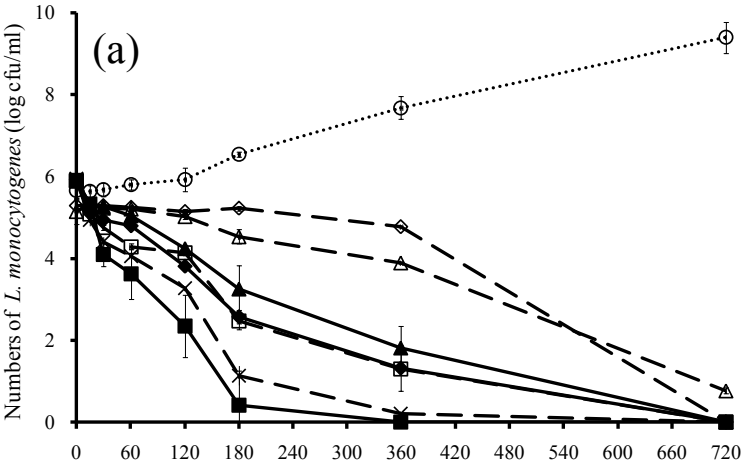

Time $(\min )$

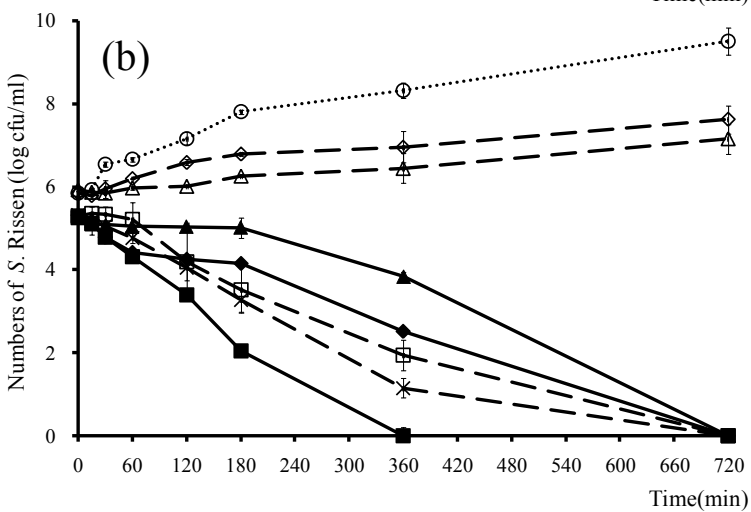

Fig. 3 Survivors curves of (a) L. monocytogenes TSULM1 and (b) $\mathrm{S}$. Rissen in $\mathrm{MHB}$ at $35^{\circ} \mathrm{C}$ as a function of organic acid salts and LAE alone (dashed line) and in combinations (solid line); control (circles), SD (squares), SC (triangles), SL (diamonds) and LAE (crosses).

combination at MBC concentration in MHB (Fig. 3). Addition of SD $(62.5 \mathrm{mg} / \mathrm{ml})$ and LAE $(0.032 \mathrm{mg} / \mathrm{ml})$ to the culture media caused a sharp drop in both bacterial counts after $360 \mathrm{~min}$, and values under two log cycle were maintained for the remainder of the time studied. LAE proved to be more effective against both bacteria in MHB than the three salts of organic acid $(p<0.05)$. Moreover, SC $(62.5 \mathrm{mg} / \mathrm{ml})$ and SL $(8.4 \%$ $\mathrm{v} / \mathrm{v})$ alone was not active in killing $S$. Rissen. SC and SL had little effect on $S$. Rissen counts until 120 and $60 \mathrm{~min}$, respectively, and subsequently, bacterial counts increased by more than one log cycle after a further 600 and $660 \mathrm{~min}$, respectively. After an incubation period of $180 \mathrm{~min}$, the combination of SD with LAE at sub-bactericidal concentrations reduced $L$. monocytogenes and $S$. Rissen counts by greater than five and four log cycles, respectively, compared with the initial bacterial load. The bacterial counts found in MHB containing salts of organic acid alone were significantly higher $(p<0.05)$ than the counts obtained for the broth to which had been added the
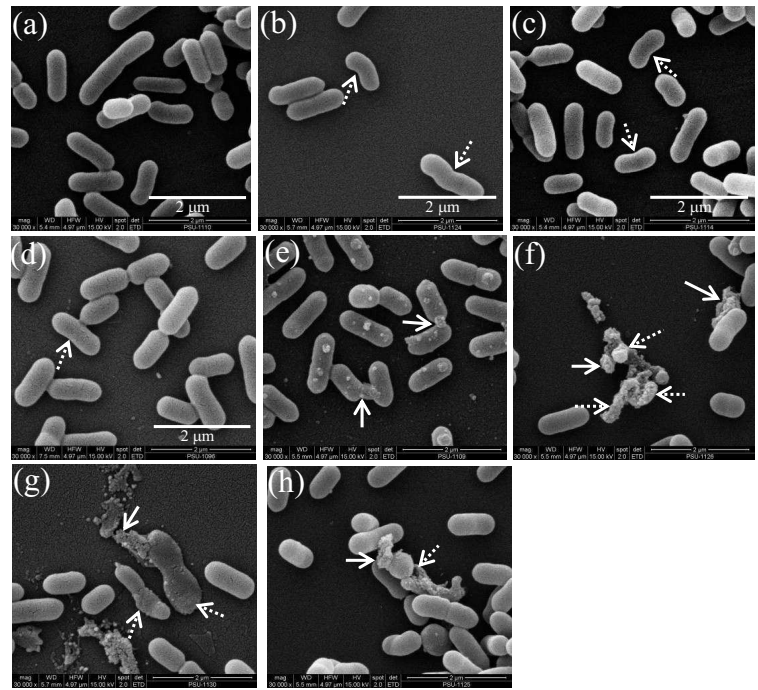

Fig. 4 Scanning electron micrographs of L. monocytogenes TSULM1 in MHB containing antimicrobials: (a) control, (b) $62.5 \mathrm{mg} / \mathrm{ml}$ of SD, (c) $62.5 \mathrm{mg} / \mathrm{ml}$ of SC, (d) $8.4 \%(\mathrm{v} / \mathrm{v})$ of SL, (e) $0.032 \mathrm{mg} / \mathrm{ml}$ of LAE, (f) $7.8 \mathrm{mg} / \mathrm{ml}$ of SD + $0.002 \mathrm{mg} / \mathrm{ml}$ of LAE, $(\mathrm{g}) 15.6 \mathrm{mg} / \mathrm{ml}$ of SC and $0.008 \mathrm{mg} / \mathrm{ml}$ of LAE, and (h) $2.1 \%(\mathrm{v} / \mathrm{v})$ of SL $+0.008 \mathrm{mg} / \mathrm{ml}$ of LAE at $35^{\circ} \mathrm{C}$ for $720 \mathrm{~min}$, except (e) and (f) for $360 \mathrm{~min}$. Membrane cells were disturbed and leaked (solid arrow) and subsided (hatched arrow). Bars $=2 \mu \mathrm{m}$.

mixture of $7.8 \mathrm{mg} / \mathrm{ml} \mathrm{SD}$ and $0.002 \mathrm{mg} / \mathrm{ml} \mathrm{LAE}$, the mixture of $15.6 \mathrm{mg} / \mathrm{ml} \mathrm{SC}$ and $0.008 \mathrm{mg} / \mathrm{ml} \mathrm{LAE}$, and the mixture of $2.1 \%(\mathrm{v} / \mathrm{v}) \mathrm{SL}$ and $0.008 \mathrm{mg} / \mathrm{ml}$ LAE.

\section{Scanning electron microscopy (SEM) and transmission electron microscopy (TEM)}

Cells of L. monocytogenes TSULM1 and S. Rissen TSUSR1 treated with SD, SC, SL, and LAE alone and in combination underwent considerable morphological alterations in comparison with the control when studied by SEM ((Figs. 4 and 6) and TEM (Figs. 5 and 7). Untreated cells of L. monocytogenes TSULM1 (control) appear as a smooth bacilli (Figs. 4a and 5a). Treated cells lost and changed the cytoplasm following exposure to SD, SC, and SL (Figs. 5b, 5c, and 5d). For LAE, some membrane leakage was observed (Figs. 4e and 5e). The images demonstrated that LAE led to dramatic changes in cell envelope, indicating that membranes are the main target of this substance. This hypothesis agrees with the results showing that LAE interacts with the lipids from the bacterial membranes disturbing the membrane potential and causing structural changes in $S$. Typhimurium and $S$. aureus $^{45}$. Images obtained in the present study demonstrated that LAE also disrupts the membrane 


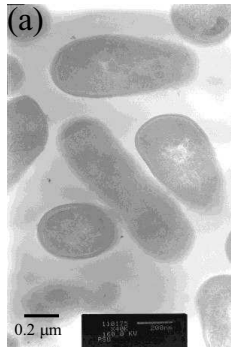

(d)

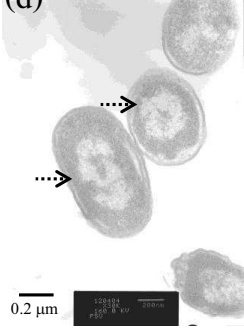

(g)
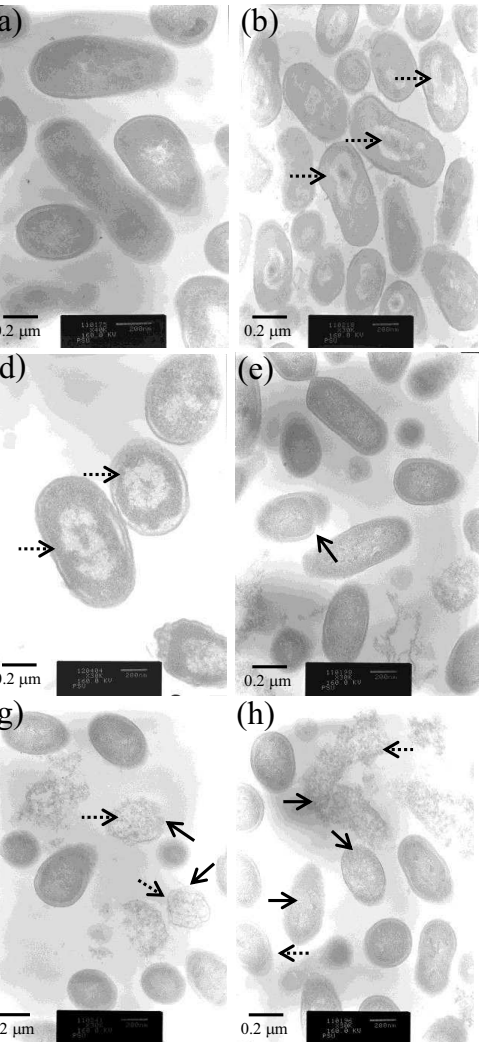

(c)

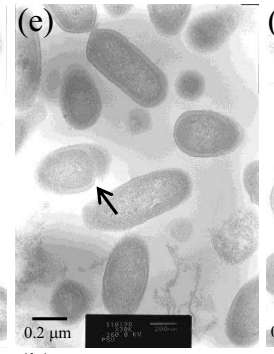

(e)

(h)

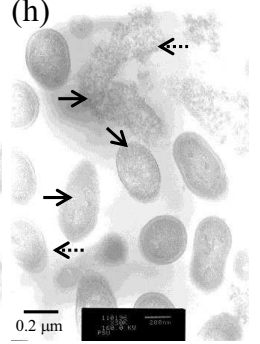

Fig. 5 Transmission electron micrographs of L. monocytogenes TSULM1 in MHB containing antimicrobials: (a) control, (b) $62.5 \mathrm{mg} / \mathrm{ml}$ of SD, (c) $62.5 \mathrm{mg} / \mathrm{ml}$ of SC, (d) $8.4 \%$ (v/v) of SL, (e) $0.032 \mathrm{mg} / \mathrm{ml}$ of LAE, (f) $7.8 \mathrm{mg} / \mathrm{ml}$ of SD + $0.002 \mathrm{mg} / \mathrm{ml}$ of LAE, $(\mathrm{g}) 15.6 \mathrm{mg} / \mathrm{ml}$ of SC and $0.008 \mathrm{mg} / \mathrm{ml}$ of LAE, and (h) $2.1 \%(\mathrm{v} / \mathrm{v})$ of SL $+0.008 \mathrm{mg} / \mathrm{ml}$ of LAE at $35^{\circ} \mathrm{C}$ for $720 \mathrm{~min}$, except (e) and (f) for $360 \mathrm{~min}$. Membrane cells were disturbed and leaked (solid arrow) and subsided (hatched arrow). Bars $=0.2 \mu \mathrm{m}$.

of $E$. coli, producing leakage of cytosolic components and subsequent cell death. The results obtained in the survival study agree with this hypothesis, since LAE showed fast bactericidal activity that is in consistent with a fast mechanism of action such as membrane disruption. In all cells exposed to the combinations of antimicrobials, the cytoplasm was disorganized and the integrity of the membrane was compromised (Figs. 4f, 4g, 4h, 5f, 5g and 5h) and the antimicrobial activity was higher when compared with that of the antimicrobials alone. This could be due to the presence of LAE improving the uptake of undissociated organic acid salts into the membrane, which probably affects membrane function and furthermore leads to measurable synergism of the combined antimicrobial treatment $^{45}$. For $S$. Rissen TSUSR1, cells treated
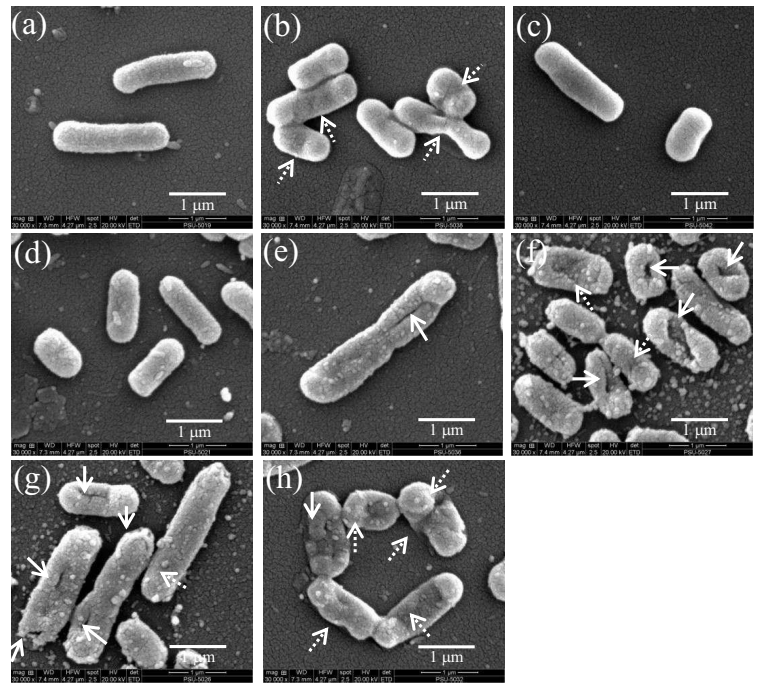

Fig. 6 Scanning electron micrographs of $S$. Rissen TSUSR1 in MHB containing antimicrobials: (a) control, (b) $62.5 \mathrm{mg} / \mathrm{ml}$ of SD, (c) $62.5 \mathrm{mg} / \mathrm{ml}$ of SC, (d) $8.4 \%(\mathrm{v} / \mathrm{v})$ of SL, (e) $0.032 \mathrm{mg} / \mathrm{ml}$ of LAE, (f) $7.8 \mathrm{mg} / \mathrm{ml}$ of SD + $0.002 \mathrm{mg} / \mathrm{ml}$ of LAE, (g) $15.6 \mathrm{mg} / \mathrm{ml}$ of SC and $0.008 \mathrm{mg} / \mathrm{ml}$ of LAE, and (h) $2.1 \%(\mathrm{v} / \mathrm{v})$ of SL $+0.008 \mathrm{mg} / \mathrm{ml}$ of LAE at $35^{\circ} \mathrm{C}$ for $720 \mathrm{~min}$, except (e) and (f) for $360 \mathrm{~min}$. Membrane cells were disturbed and leaked (solid arrow) and subsided (hatched arrow). Bars $=1 \mu \mathrm{m}$.

with salts of organic acid and LAE alone and in combination appeared similar to cells of L. monocytogenes TSULM1, except for SC alone and SL alone (Figs. 6c, 6d, 7c, and 7d), for which the membrane and cytoplasm of cells were not different from untreated cells.

In summary, this study confirms that salts of organic acid and LAE alone and in combination exhibit in vitro antimicrobial effects against $L$. monocytogenes TSULM1 and $S$. Rissen TSUSR1 S. aureus, isolated from pig carcasses. There was a synergistic effect of LAE in the presence of SD, SC, and SL probably due to increased uptake of the fatty acids into the membrane, resulting in membrane disruption. However, whether they can be used for food or meat preservation, issues of in vivo antimicrobial activity and sensory effects during storage would need to be addressed.

Acknowledgements: This study was supported by grants from the General Research Fund of Thaksin University in 2012. The authors would like to thank the Thai Government for support through the General Research Fund of Thaksin University. 


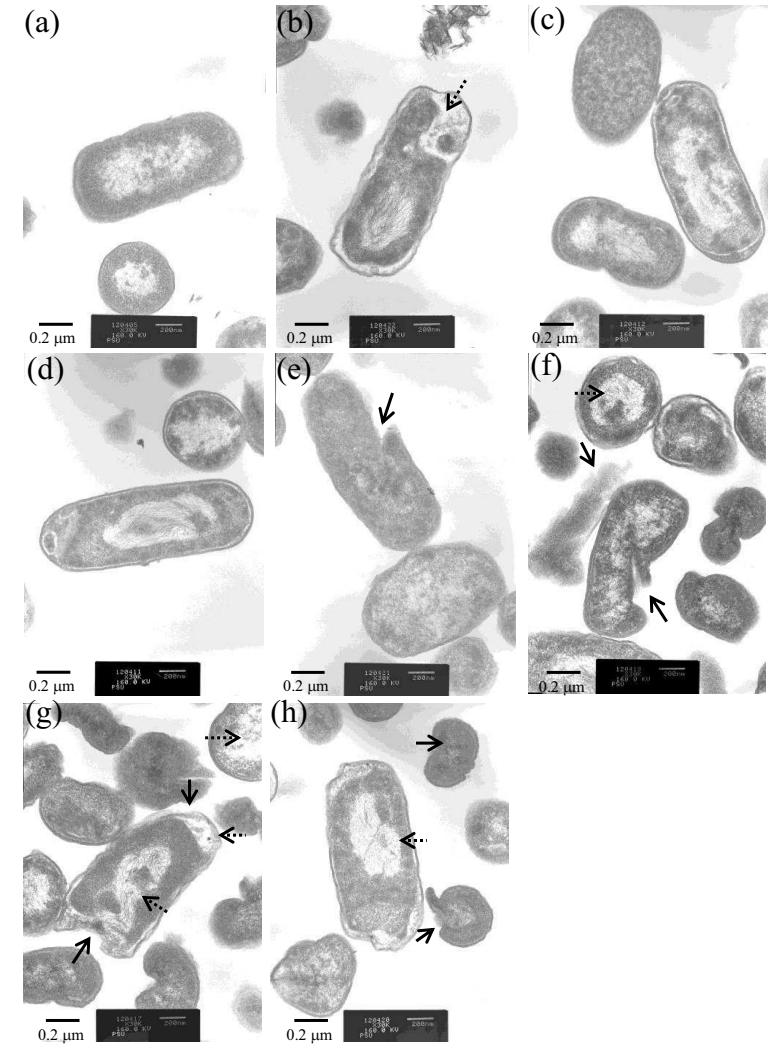

Fig. 7 Transmission electron micrographs of $S$. Rissen TSUSR1 in MHB containing antimicrobials: (a) control, (b) $62.5 \mathrm{mg} / \mathrm{ml}$ of SD, (c) $62.5 \mathrm{mg} / \mathrm{ml}$ of SC, (d) $8.4 \%$ (v/v) of SL, (e) $0.032 \mathrm{mg} / \mathrm{ml}$ of LAE, (f) $7.8 \mathrm{mg} / \mathrm{ml}$ of SD +0.002 $\mathrm{mg} / \mathrm{ml}$ of LAE, $(\mathrm{g}) 15.6 \mathrm{mg} / \mathrm{ml}$ of SC and $0.008 \mathrm{mg} / \mathrm{ml}$ of $\mathrm{LAE}$, and (h) $2.1 \%(\mathrm{v} / \mathrm{v})$ of SL $+0.008 \mathrm{mg} / \mathrm{ml}$ of LAE at $35^{\circ} \mathrm{C}$ for $720 \mathrm{~min}$, except (e) and (f) for $360 \mathrm{~min}$. Membrane cells were disturbed and leaked (solid arrow) and subsided (hatched arrow). Bars $=0.2 \mu \mathrm{m}$.

\section{REFERENCES}

1. McLauchlin J, Mitchell RT, Smerdon WJ, Jewell K (2004) Listeria monocytogenes and listeriosis: a review of hazard characterisation for use in microbiological risk assessment of foods. Int J Food Microbiol 92, 15-33.

2. Anonymous (2003) Zoonoses: Commissioner David Byrne welcomes new legislation to combat food-borne diseases such as Salmonella (IP/03/1306). European Commission.

3. Grimont PAD, Grimont F, Bouvet P (2000) Taxonomy of the Genus Salmonella. In: Wray C, Wray A (eds) Salmonella in Domestic Animals, 1st edn, CABI Publishing, Oxon, UK, pp 1-17.

4. Tangwatcharin P, Wattanachant C (2008) Contamination of pathogens in hygienic and unhygienic slaughtering and cutting process in municipality of Hat Yai City,
Songkhla province. Research Report of Thai Health Promotion Foundation, Thailand.

5. Tangwatcharin P, Wattanachant C (2009) Bacterial contaminations in floor and hanging pig slaughtering processes in municipality of Hat Yai City, Songkhla province. King Mongkuts Agr J 27, 122-31.

6. Mbandi E, Shelef LA (2001) Enhanced inhibition of Listeria monocytogenes and Salmonella enteritidis in meat by combinations of sodium lactate and diacetate. J Food Protect 64, 640-4.

7. Miller AJ, Call JE, Whiting RC (1993) Comparison of organic acid salts for Clostridium botulinum control in uncured turkey. J Food Protect 56, 958-62.

8. Scannell AGM, Hill C, Buckley DJ, Arendt EK (1997) Determination of the influence of organic acids and nisin on shelf-life and microbiological safety aspects of fresh pork. J Appl Microbiol 83, 407-12.

9. Becerril R, Manso S, Nerin C, Gómez-Lus R (2013) Antimicrobial activity of Lauroyl Arginate Ethyl (LAE), against selected food-borne bacteria. Food Contr 32, 404-8.

10. Hawkins DR, Rocabayera X, Ruckman S, Segret R, Shaw D (2009) Metabolism and pharmacokinetics of ethyl $\mathrm{N}^{\alpha}$-lauroyl-L-arginate hydrochloride in human volunteers. Food Chem Toxicol 47, 2711-5.

11. Hitchins AD, Jinneman K (2013) Detection and enumeration of Listeria monocytogenes in foods. Bacteriological Analytical Manual (BAM) Online, Ch. 10. U.S. Food and Drug Administration. URL: http://www.fda.gov/Food/FoodScienceResearch/ LaboratoryMethods/ucm071400.htm.

12. Andrews WH, Jacobson A, Hammack T (2011) Salmonella. Bacteriological Analytical Manual (BAM) Online, Ch. 5. U.S. Food and Drug Administration. URL: http://www.fda.gov/Food/FoodScienceResearch/ LaboratoryMethods/ucm070149.htm.

13. Bauer AW, Kirby WMM, Sherris JC, Turck M (1966) Antibiotic susceptibility testing by a standardized single disk method. Am J Clin Pathol 45, 493-6.

14. CLSI (2002) Reference method for dilution antimicrobial susceptibility tests for bacteria that grow aerobically. Approved standard M7-A4. Wayne, Pa: Clinical Laboratory Standards Institute.

15. Bharadwaj R, Vidya A, Dewan B, Pal A (2003) An in vitro study to evaluate the synergistic activity of norfloxacin and metronidazole. Indian J Pharmacol 35, $220-6$.

16. Doores S (2005) Organic acids. In: Davidson PM, Sofos JN, Branen AL (eds) Antimicrobials in Food, 3rd edn, CRC Press, Boca Raton, FL, pp 91-142.

17. Gutierrez J, Barry-Ryan C, Bourke P (2008) The antimicrobial efficacy of plant essential oil combinations and interactions with food ingredients. Int J Food Microbiol 124, 91-7.

18. de Oliveira CEV, Stamford TLM, Gomes Neto NJ, de Souza EL (2010) Inhibition of Staphylococcus aureus in broth and meat broth using synergies of phenolics 
and organic acid. Int J Food Microbiol 137, 312-6.

19. Tangwatcharin P, Chanthachum S, Khopaibool P, Griffiths MW (2007) Morphological and physiological responses of Campylobacter jejuni to stress. J Food Protect 69, 2747-53.

20. Chaveerach P, Keuzenkamp DA, Urlings HA, Lipman LJ, van Knapen F (2002) In vitro study on the effect of organic acids on Campylobacter jejuni/coli populations in mixtures of water and feed. Poultry Sci 81, 621-8.

21. Zakaria Z, Sreenivasan S, Mohamad M (2007) Antimicrobial activity of Piper ribesoides root extract against Staphylococcus aureus. J Appl Biol Sci 1, 87-90.

22. Serdengecti N, Yildirimi I, Gokoglu N (2006) Effects of sodium lactate, sodium acetate and sodium diacetate o $\mathrm{n}$ microbiological quality of vacuum-packed beef during refrigerated storage. J Food Saf 26, 62-71.

23. Ukuku DO, Bari ML, Kawamoto S, Isshiki K (2005) Use of hydrogen peroxide in combination with nisin, sodium lactate and citric acid for reducing transfer of bacterial pathogens from whole melon surfaces to fresh-cut pieces. Int J Food Microbiol 104, 225-33.

24. Apostolidis E, Kwon Y-I, Shetty K (2008) Inhibition of Listeria monocytogenes by oregano, cranberry and sodium lactate combination in broth and cooked ground beef systems and likely mode of action through proline metabolism. Int J Food Microbiol 128, 317-24.

25. Hwang C-A, Sheen S, Juneja V (2011) Effects of sodium lactate on the survival of Listeria monocytogenes, Escherichia coli O157: H7, and Salmonella spp. in cooked ham at refrigerated and abuse temperatures. Food Nutr Sci 2, 464-70.

26. McMahon CMM, Doherty AM, Sheridan JJ, Blair IS, McDowell DA, Hegarty T (1999) Synergistic effect of heat and sodium lactate on the thermal resistance of Yersinia enterocolitica and Listeria monocytogenes in minced beef. Lett Appl Microbiol 28, 340-4.

27. Shelef LA, Yang Q (1991) Growth suppression of Listeria monocytogenes by lactates in broth, chicken, and beef. J Food Protect 54, 283-7.

28. Silva ENG, Almeida RCC, Figueiredo ACL, Miranda FA (2012) Effects of salts of organic acids on the survival of Listeria monocytogenes in soft cheeses. Int J Food Sci Tech 47, 1819-25.

29. Ibrahim SA, Yang H, Seo CW (2008) Antimicrobial activity of lactic acid and copper on growth of Salmonella and Escherichia coli 0157:H7 in laboratory medium and carrot juice. Food Chem 109, 137-43.

30. Glass KA, Granberg DA, Smith AL, McNamara AM, Hardin M, Mattias J, Ladwig K, Johnsoni EA (2002) Inhibition of Listeria Monocytogenes by sodium diacetate and sodium lactate on wieners and cooked bratwurst. J Food Protect 65, 116-23.

31. Stekelenburg FK (2003) Enhanced inhibition of Listeria monocytogenes in frankfurter sausage by the addition of potassium lactate and sodium diacetate mixtures. Food Microbiol 20, 133-7.

32. Legan JD, Seman DL, Milkowski AL, Hirschey JA,
Vandeven MH (2004) Modeling the growth boundary of Listeria monocytogenes in ready-to-eat cooked meat products as a function of the product salt, moisture, potassium lactate, and sodium diacetate concentrations. J Food Protect 67, 2195-204.

33. Abou-Zeid KA, Yoon KS, Oscar TP, Schwarz JG, Hashem FM, Whiting RC (2007) Survival and growth of Listeria monocytogenes in broth as a function of temperature, $\mathrm{pH}$, and potassium lactate and sodium diacetate concentrations. J Food Protect 70, 2620-5.

34. Houtsma PC, de Wit JC, Rombouts FM (1993) Minimum inhibitory concentration (MIC) of sodium lactate for pathogens and spoilage organisms occurring in meat products. Int J Food Microbiol 20, 247-57.

35. Watanabe R, Hojo K, Nagaoka S, Kimura K, Ohshima T, Maeda N (2011) Antibacterial activity of sodium citrate against oral bacteria isolated from human tongue dorsum. J Oral Biosci 53, 87-92.

36. Patel JR, Sanglay GC, Solomon MB (2009) Control of Listeria monocytogenes on frankfurters with antimicrobials and hydrodynamic pressure processing. J Muscle Foods 20, 227-41.

37. Uhart M, Ravishankar S, Maks N (2004) Control of Listeria monocytogenes with combined antimicrobials on beef franks stored at $4{ }^{\circ} \mathrm{C} . J$ Food Protect 67, 2296-301.

38. DeVegt B (1999) Lactate controls Listeria monocytogenes. PURAC, Lincolnshire, IL, America.

39. Houtsma PC, de Wit JC, Rombouts FM (1996) Minimum inhibitory concentration (MIC) of sodium lactate and sodium chloride for spoilage organisms and pathogens at different $\mathrm{pH}$ values and temperatures. J Food Protect 59, 1300-4.

40. Nanasombat S, Chooprang K (2009) Control of pathogenic bacteria in raw pork using organic acid salts in combination with freezing and thawing. Kasetsart $J$ (Nat Sci) 43, 576-83.

41. Brandt AL, Castillo A, Harris KB, Keeton JT, Hardin MD, Taylor TM (2010) Inhibition of Listeria monocytogenes by food antimicrobials applied singly and in combination. J Food Sci 75, M557-63.

42. Manso S, Nerín C, Gómez-Lus R (2011) Antifungal activity of the essential oil of cinnamon (Cinnamomum zeylanicum), oregano (Origanum vulgare) and lauramide argine ethyl ester (Lae) against the mold Aspergillus flavus Cect 2949. Ital J Food Sci SLIM2010, 151-7.

43. Pezo D, Navascués B, Salafranca J, Nerín C (2012) Analytical procedure for the determination of Ethyl Lauroyl Arginate (LAE) to assess the kinetics and specific migration from a new antimicrobial active food packaging. Anal Chim Acta 745, 92-8.

44. Aznar M, Gómez-Estaca J, Vélez D, Devesa V, Nerín C (2013) Migrants determination and bioaccessibility study of ethyl lauroyl arginate (LAE) from a LAE based antimicrobial food packaging material. Food Chem Toxicol 56, 363-70. 
45. Shelef LA (1994) Antimicrobial effects of lactates: A review. J Food Protect 57, 445-50.

46. Russell JB (1992) A review: Another explanation for the toxicity of fermentation acids at low $\mathrm{pH}$ : anion accumulation versus uncoupling. J Appl Bacteriol 73, 363-70.

47. Stratford M (2000) Traditional preservatives organic acids. In: Robinson RK, Batt CA, Patel PD (eds) Encyclopedia of Food Microbiology volume 1, 1st edn, Academic Press, New York. pp 1729-37.

48. Rodríguez E, Seguer J, Rocabayera X, Manresa A (2004) Cellular effects of monohydrochloride of L-arginine, $\mathrm{N}^{\alpha}$-lauroyl ethylester (LAE) on exposure to Salmonella typhimurium and Staphylococcus aureus. J Appl Microbiol 96, 903-12. 